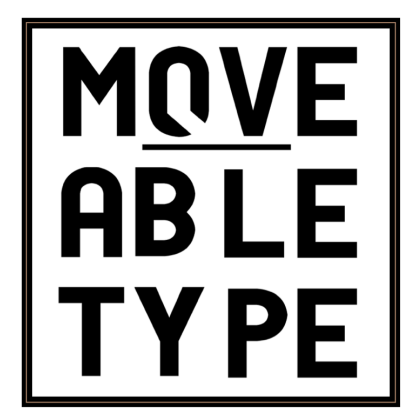

Empire Windrush: Cultural Memory and Archival Disturbance

Author[s]: Matthew Mead

Source: MoveableType, Vol.3, 'From Memory to Event (2007)

DOI: $10.14324 / 111.1755-4527.027$

MoveableType is a Graduate, Peer-Reviewed Journal based in the Department of English at UCL.

(C) 2007 Matthew Mead. This is an Open Access article distributed under the terms of the Creative Commons Attribution License (CC-BY) 4.0https://creativecommons.org/licenses/by/4.0/, which permits unrestricted use, distribution, and reproduction in any medium, provided the original author and source are credited.

\title{
UCLPRESS
}




\section{Empire Windrush Cultural Memory and Archival Disturbance}

by Matthew Mead

uhammad Anwar states unequivocally, in a history of New
Commonwealth migration, that the 'start of mass migration [to the UK] was the arrival of the Empire Windrush ship in June 1948'. ${ }^{1}$ The reporting of the arrival of the Windrush with its carriage of 492 Jamaicans is now so ubiquitous that, as Paul Carter suggests-with reference to another historical arrival of Cook's landing at Botany Bay'the spatial event is replaced by a historical stage'. ${ }^{2}$ Curiously, a history of mobility is in danger of becoming immutable. I would like to suggest that the figuring of the Windrush as a symbolic arrival of the Other is a product of at least three archives. No considered interpretation of the Windrush is possible without influence from and reaction to all three archives. The meaning of the event is as much produced in the form of its construction as it is through its content, so that the histories produced are not only selective, but indicative of a specific cultural imagination. I would also wish to caution against an absolute separation between the suggested archives. I propose instead that the archives are by degrees mutually constitutional.

The first archive we might call historical and is located in the text and images of documentary evidence. This archive allows us to establish the 'facts' of the Windrush such that we can reach a broad consensus on the place and time of arrival, the geographical trajectory 
and history of the vessel, and the number and nationalities of the passengers. Contemporary documentation, such as the ship's passenger log and newspapers from the time provide a textual access to the event subject, but inevitably leads to ambiguity and fallibility, depending on the physical condition of the text and the conditions of textuality.

The second archive is constituted by cultural memory and imagination, is not divorced from history, and is sympathetic to the British post-war postcolonial immigrations. While this archive is sensitive to and enthusiastic about the long historical presence of black and Asian people within Britain's borders, it also wishes to emphasise a transition from a limited and fragile presence in the pre-war years to a significant and fundamentally unassimilable presence, signalled by the arrival of the Windrush in 1948.

The third archive responds to a reactionary nationalism. Again, this archive is produced by cultural memory and imagination. While an amnesia surrounding an early presence of black and Asian migrants dating back hundreds of years may be nurtured, an emphasis redolent of the second archive is placed on the post-war arrivals who must be either excluded or assimilated rather than celebrated. I will consider that the reference to the historical initially unsettles, but ultimately confirms, the symbolic significance accorded the arrival of the Windrush.

In the essay 'The Pioneers: Fifty Years of Caribbean Migration to Britain', Caryl Phillips suggests that early Caribbean migrants were travelling as a generation of people who often thought of themselves as intimately linked with their destination; they felt 'a profound affiliation to the land which lay before them'. ${ }^{3}$ With 'high unemployment, low wages, and chronic lack of opportunity' at home, they travelled with hopes and expectations of cultural acceptance and economic advancement. ${ }^{4}$ Their appearance on the horizon therefore assumes heroic qualities:

I have imagined the scene many times. We are in the late 1940s, or in the 1950s, or even in the early 1960s. Crowds of young West Indians are peering from the deck of a ship, eagerly securing their first view of the white cliffs of Dover. Before them lies a new land and a new future. At the moment of that first sighting I imagine that their dominant emotion would have been that of a profound sense of loss, for clearly they knew that it would be many years before they would 
return home to loved ones and familiar landscapes. A significant page in the narrative of their young lives was being turned; people and places were being confined to an earlier chapter. These emigrants were chained now to the future. A future in Britain. And, of course, they expected. ${ }^{5}$

There is a certain singularity about the appearance of these West Indians. Though Phillips historicizes, the 1940s, '50s, and '60s become synchronous; the imagination here homogenises and obscures. Though this is no doubt appropriate in trying to imagine the disparate arrivals of sometimes only a few dozen migrants as a coherent moment of profound cultural change, this moment was actually composed of temporally and spatially distinct events collectively producing a sociohistorical trend. Phillips's account includes the crowds aboard not only the Windrush, but other ships-the Orbita, the Reina del Pacifico, and the Georgic among others. Many of these ships would have never seen the southeast coast of England during the course of their voyage, yet in Phillips's account, they encounter the white cliffs of Dover en masse. ${ }^{6}$ Phillips's text symbolically describes a clash between competing geographical imaginations. In Small Acts, Paul Gilroy suggests that in the post-war era, racism finds its expression through cultural differences identified by the symbols and practices of nationalism. A 'populist" ${ }^{7}$ racism excludes black Britain from the 'true' markers of national belonging constructed out of the symbols and practices of the Blitz spirit, ${ }^{8}$ the national flag, ${ }^{9}$ traditional schooling, ${ }^{10}$ and adherence to English law. ${ }^{11}$ It would in no way overextend this list to include the white cliffs of Dover among these symbols of national identity, since this is also, of course, a very real geological formation that happens to mark a national border. Symbolically, as this homogenised and unreal mass of migrants encounters a reactionary nationalist imaginary, the predicted sense of homecoming is replaced by one of loss. ${ }^{12}$ More frequently than any other, this moment is metonymically narrated through the history of the Windrush; as Mike Phillips and Trevor Phillips acknowledge, 'the moment of arrival captured by the Windrush has become a symbol for all those occasions when we, or any of the other black people who have become part of the British nation, stepped off our separate gangplanks'. ${ }^{13}$ I would like to suggest that the shorthand symbolic usage of the Windrush tends towards the monadic. Moreover, the historical 
archive is inconsistent with the current treatment of the event, though ultimately these inconsistencies serve to assert the significance and weight of the Windrush as a culturally imagined moment of arrival.

To take an example that assumes many of the most common aspects of the reporting of this history, John McLeod reports that the 'SS Empire Windrush [...] docked at Tilbury on 22 June 1948, with 492 Caribbean migrants aboard seeking a new life in London'. ${ }^{14}$ This is not in any way an exceptional claim; rather, it is typical. It seems to record verifiable historical fact. However, the reported date, location, number of passengers, and even the syntax of the statement detach themselves from any particular instance of authorship, as each is repeated across the pages of various cultural texts, which are produced by historians, literary critics, and cultural theorists. This cumulative sedimentation of fact is sometimes homogenised further by the inclusion of additional details that stress the migrants' nationality as singularly Jamaican and their gender as exclusively male. I cite several examples from that archive of cultural memory sympathetic to those post-war arrivals: 'on 22 June 1948, the SS Empire Windrush docked at Tilbury and discharged 492 Jamaican migrants'; ${ }^{5}$ 'In June 1948 the S. S. Empire Windrush docked at Tilbury and 492 Jamaicans disembarked'; ${ }^{16}$ 'on 22 June 1948, the SS Empire Windrush docked at Tilbury. Four hundred and ninety-two West Indian emigrants disembarked'; 17 'The start of mass migration was the arrival of the Empire Windrush ship in June 1948. It came to Tilbury docks with 492 immigrants from Jamaica'; 18 'on 22 June 1948, 492 Jamaicans disembarked from the Empire Windrush and thus began the pattern of migration to the motherland'; 19 'On 22 June, 1948, the Empire Windrush landed 492 Jamaicans at Tilbury'; 20 'as England gradually withdrew its imperial tentacles, hundreds of thousands of former subjects went along for the ride, beginning with the arrival of 492 Caribbean immigrants on the SS Windrush in 1948'; 'the "bombshell" arrival of the Empire Windrush in June 1948 with 492 Jamaicans aboard';22 'On 22 June 1948, the author of this book, then a young reporter on a national newspaper, went to Tilbury to see 492 Jamaicans come ashore from the Empire Windrush'; 23 'the Empire Windrush anchored at Tilbury docks in Kent, June 221948 [...] Four hundred and ninety two West Indians disembarked'. ${ }^{24}$ Barnor Hesse, ${ }^{25}$ 
Wendy Webster, ${ }^{26}$ Robert Winder, ${ }^{27}$ and Mark Stein in conversation with David Dabydeen ${ }^{28}$ all echo these facts and figures in only slightly differing syntax. Peter Fraser, ${ }^{29}$ Winston James, ${ }^{30}$ Sarita Malik, ${ }^{31}$ Harry Goulbourne, ${ }^{32}$ and Onyekachi Wambu ${ }^{33}$ use these facts selectively, though all acknowledge the Windrush as the inauguration of post-war migration to Britain. Fryer, ${ }^{34}$ Webster, ${ }^{35}$ Wambu, ${ }^{36}$ and Webster's own source, Claudette Williams, ${ }^{37}$ all gender the migrants as men. ${ }^{38}$

Newspapers from the time vary in their estimates; the Daily Express counts ' 450 Jamaican men' on 21 June, ${ }^{39}$ and Peter Fryer, at the time a journalist for the Daily Worker, rounds this number up to ' 500 Jamaicans' two days later. ${ }^{40}$ The Times on 23 June, however, appears to be the first to pinpoint the $492 .{ }^{41}$ The iteration of this figure marks a transformation of the event from a collection of multiple individual histories to a composite, symbolic, imagined, and monadic moment of arrival. The figure, repeated across these pages, ceases to only occupy its cardinal position to mark quantity. The number instead comes to stand metonymically for a myth of post-war migration, thus permitting a range of equally symbolic readings of the event. As an example, these imagined 492 economic migrants from Jamaica, all men, provide an ironic counterpoint to Doreen Massey's thinking on the construction of home. Massey contends that the female 'Other' is seen in opposition to the invariably male figure of the explorer, 'setting out to discover and change the world'. ${ }^{42}$ The myth of the Windrush migrants both mimics and opposes such thinking; yes, these (imagined) immigrants are all men, but their motives for, and direction of, travel undermine a figuring of them as patriarchal explorers in the traditional sense. In fact, in Massey's own words, they represent 'the arrival in one form or another of the "Other". ${ }^{43}$ It is thus that Wendy Webster is able to critique a patriarchal model of travel by acknowledging the presence onboard the Windrush of the 'woman stowaway-Averilly Wauchope, a dressmaker from Kingston'. ${ }^{44}$ Although Webster, an academic in women's history, does not pursue a theoretical reading of the stowaway, this named female critiques the standard model employed in reporting the ship's arrival within the imagined history of the Windrush. This detail challenges both the gendering of travel discourse and the writings of cultural theorists who do not look beyond the 492 Jamaican men. The 
story of Averilly Wauchope becomes a history of the marginalised within the marginalised, which would seem to both confirm and challenge the dominant myth. Not only is Wauchope in a minority, but she is hidden, confirming the pioneer visibly as a male figure. However, her presence also challenges the accepted mythology, by revealing Wauchope as a repressed dynamic in the reporting of, or imagining of, the event. This of course should not be confused with a female recuperation of power in the history of economic migration.

However, this reading of Wauchope and the monadic immutability of the 492 are unsettled by returning to the historical archive. The often repeated 'facts' of the Windrush, including the date of the vessel's arrival, the gendering of the migrants, the uncomplicated route of the Windrush from Kingston to Tilbury, the names and number of stowaways, and most significantly, the number and nationalities of the migrants on board are all disturbed by reference to the passenger log, government papers, and newspapers from the time. To begin with an item that seems relatively trivial- though of course through repetition these facts assert themselves as anything but trivial — the date of arrival on the passenger log is marked ' 21 ' rather than ' 22 June', suggesting a night in port before disembarkation. ${ }^{45}$ The final entries in the log also reveal that the stowaway, Wauchope, had company; Samuel Johnson from Trinidad had also managed to board without paying. Through this initial reading of the log, then, the neat symbolic reading of Averilly Wauchope as repressed female dynamic is undermined. However, it is prudent also to acknowledge the fallibility of the log, which unsurprisingly does not provide unproblematic access to the past. The stowaway whom Claudette Williams and Wendy Webster name 'Averilly Wauchope' is recorded in the log as 'Evelyn Wauchape'. Furthermore, Fryer's article of 23 June names her 'Evelyn Wauchbe'. Complicating matters further, a reporter for the Evening Standard interviewing the stowaway refers to her as Avril. In the same article Wauchope/Wauchape/Wauchbe's special status as stowaway is diminished further; it is claimed that 'Late this afternoon [22 June] the last Jamaican left the Empire Windrush. [...] He was another stowaway, the 18th discovered since the ship sailed'. ${ }^{46}$ 
However, the omission of these stowaways from the standard account of the Windrush represents neither the most significant, nor the most striking absence from the record of the 492 migrants. The passenger $\log$, with its omissions, inaccuracies and ambiguities, nevertheless reveals the Jamaican passengers as only half a story; the total listed passengers - and these include Wauchope and Johnson, though not, it would seem, the other stowaways - actually add up to 1027, more than double the figure suggested in the standard accounts. Mark Stein, author of Black British Literature, visited the Museum of London exhibition 'Windrush: Sea Change' in $1998^{47}$ and apparently saw the passenger log on loan from the Public Record Office. He erroneously records the total tally of passengers as '1024', though quite correctly states that 'It is common to mention only the 492 West Indian migrants'. ${ }^{48}$ It is revealing then that having discovered the unsettling nature of the log, Stein is compelled to bury these previously hidden details within the notes at the end of the text. Only by marginalising what is already repeatedly not said about the Windrush can Stein retain this moment of arrival as the uncomplicated origin of post-war postcolonial migration and thus substantiate the received narrative of black Britain that his study hopes to reproduce. Thus in Stein's account, the Windrush is apparently able to retain its mythic role of inauguration, making a significant, and of course expected, appearance at the threshold of his text. ${ }^{49}$

Just as the ending of Stein's study would seem to unsettle the foundations of this originary narrative, so too the ending of the $\log$ disturbs another facet of the Windrush myth. Before we forget the stowaway Samuel Johnson, the 1027th passenger recorded in the $\log$, it is worth noting his 'Country of last Permanent Residence', Trinidad. As this suggests, the uncomplicated route of the Windrush from Kingston to London, with its homogenised carriage of Jamaicans, represents too simple a story. Trinidad is in fact recorded as the first port of embarkation, followed then by Jamaica, Tampico, Havana, and Bermuda before the Empire Windrush finally crossed the Atlantic to dock at Tilbury. Moreover, the routes of those on board would seem to be even more complex. At least 70 passengers record Trinidad as their 'Country of last Permanent Residence', while others name British Guiana, St Lucia, Uganda, Kenya, Barbados, Italy, and even Scotland, 
again unsettling the Jamaican focus of the Windrush myth. The log also records the intended final destination of each passenger, and while the majority of those on board nominate to settle in England, there are also those who suggest Scotland, 'Other parts of the British Empire' and elsewhere. London, and Britain, then would seem to represent an ambivalent centre. The journeys of these passengers are textually always in relation to, but not necessarily literally directed towards, the imperial metropolis. Thus while cultural histories of London quite rightly stress the significant impact of immigration and London's shifting hybrid identity, the extent to which London, or Britain, are textually inscribed as central should not be ignored.

Evidence of a less visible mass migration, which warrants some comment, is also documented in the passenger log and other contemporaneous documents. The passenger log records sixty-six migrants from Poland who had 'wandered from Siberia, via India, Australia, New Zealand and Africa to Mexico' ${ }^{50}$ before finding passage on the Windrush. The log also records that all of these migrants from Poland intended to take up residence in England. The omission of this epic and largely ignored story from postcolonial interpretations is more telling than the meagre numbers suggest. Histories of Polish immigration tell of a presence on English soil since the late Middle Ages $^{\prime 51}$ and by the late-nineteenth century an increased flow of migrants from Poland had established itself. ${ }^{52}$ During the Second World War, Polish emigres arrived in large numbers, ${ }^{53}$ and the dispersal of Poland's people and institutions led to the joke that 'Poland was the largest country in the world: its government was in London, its army was in Italy, and its population was in Siberia'. ${ }^{54}$ Clearly though, much of its population was also in the United Kingdom:

The Poles settled primarily in the cities, overwhelmingly in London, but also in Birmingham, Manchester and, on a smaller scale, in Bradford, Wolverhampton, Leeds, Nottingham, Sheffield, Coventry, Leicester and Slough. ${ }^{55}$

Census figures along with histories of the time describe a Polish post-war boom in immigration as significant as that represented by Caribbean, Indian, and Pakistani immigration-a significance that can also be extended to German and Italian immigrants, along with other European communities. ${ }^{56}$ These 'DPs', or 'displaced persons', 
who were sometimes recruited as European Voluntary Workers, arrived in the thousands in the post-war years. In the 1951 census, the figures for population by place of birth for England and Wales show that 2,024 residents were born in British Guiana; 6,447 in Jamaica; 1,569 in Trinidad; 110,767 in India; and 11,117 in Pakistan, while the numbers for those born in Poland were 151,736; for Germany 96,379; and Italy 33,159. The inclusion of these figures is not intended to undermine the significance of colonial or postcolonial immigration in the post-war years; indeed, in the 2001 census, only 58,107 Polish-born residents were recorded for England and Wales, while the Jamaicanborn numbered 145,934 . The comparability of these statistics over time is also complicated, as the national borders and governmental affiliations of different regions were by no means static in the post-war period. Restrictions imposed at borders, the shifting of those borders, and the crossings that were made bring into question the notion of a homogeneous nation. It must also be remembered that while these European, Caribbean, and Asian immigrations are part of the same historical moment, and while the events of the Second World War provided much of the impetus for the process of decolonisation, these communities nevertheless belong to largely different histories and have different historical relationships with the new host nation. Some of the motivation for discussing postcolonial immigration as a separate event in fact stems from racist British immigration policies and the resistance that these policies and a related assumed national identity necessitate, along with a corresponding experience of colonialism or imperialism 'out of which so many of the characteristic "racist" experiences and relationships in the modern world have developed'. ${ }^{57}$

For those who wish to disturb homogeneous and reactionary forms of national identity, the 492 Jamaican migrants, more than half a century after their mythic arrival, confirm and celebrate the presence of ethnically diverse and unassimilable communities within the increasingly elastic borders of Britain's national identity. To return to this figure, to the 492 , and to try instead to reclaim individual figures from the ever receding memory of history, it is revealing that the 492, who through their very repetition lose their quantitative meaning, and come to stand instead symbolically for the arrival of the Other, in fact 
seem to add up to 532. This number includes not just adult men-by the passenger log deemed to mean any male over the age of 12 -but also women, boys, and girls, and, it would seem, families.

It is not my intention here to finalise or resolve these inconsistencies. The passenger log, too, only provides a textual access to the past, which itself can be disputed. As another conspicuous example, the famous calypsonian Aldwin 'Lord Kitchener' Roberts, actually from Trinidad, is counted among the Jamaican men. He claims he had only 'spent a couple of months in Jamaica'; this, if we are still counting, would take the Jamaican number down to $531 .^{58}$ It is rather that this far more complicated history confirms the mythic arrival as a significant moment of cultural transformation. The Windrush myth attains its symbolic resonance and power not through historical accuracy, but through the repeated inscription of this 'moment' on the national consciousness as a profound moment of cultural change that confirms, validates, and values the arrival and continuing presence of ethnically diverse communities. 


\section{Bibliography}

Anwar, Muhammad, "New Commonwealth" Migration to the UK', in The Cambridge Survey of World Migration, ed. by Robin Cohen (Cambridge: Cambridge University Press, 1995), pp. 274-78 Ball, John Clement, Imagining London: Postcolonial Fiction and the Transnational Metropolis (Toronto: University of Toronto Press, 2004)

Board of Trade, London: MV Empire Windrush (New Zealand Shipping Company Ltd) Travelling from Kingston to London. Embarking at Kingston, Trinidad and Bermuda. Official Number: 181561. List of Passenger Disembarking at London. Passenger Log. BT 261237 91. National Archives, London

Carter, Paul, The Road to Botany Bay: An Exploration of Landscape and History (New York: Alfred A. Knopf, 1988)

Colonial Office, Employment of Jamaicans from the SS Empire Windrush. CO 876 88. National Archives, London

Dabydeen, David, 'Introduction', Kunapipi, 20 (1998), n.p.

Dabydeen, David, and Mark Stein, 'David Dabydeen with Mark Stein', in

Writing across Worlds: Contemporary Writers Talk, ed. by Susheila Nasta (London: Routledge, 2004), pp. 229-36

Francis, Vivienne, With Hope in Their Eyes: The Compelling Stories of the Windrush Generation (London: Nia, 1998)

Fraser, Peter, 'Africans and Caribbeans in London', in The Peopling of London: Fifteen Thousand Years of Settlement from Overseas, ed. by Nick Merriman. (London: The Museum of London, 1993), pp. 51-61

Fryer, Peter, 'Five Hundred Pairs of Willing Hands', Daily Worker, 23 June 1948, p. 3

- Staying Power: The History of Black People in Britain (London: Pluto Press Ltd, 1984)

Gallagher, J. P., '500 Hope to Start a New Life Today', Daily Express, 21 June 1948, p. 1

Gilroy, Paul, Small Acts: Thoughts on the Politics of Black Cultures (London: Serpent's Tail, 1993)

Goulbourne, Harry, Race Relations in Britain since 1945 (Basingstoke:

Macmillan Press Ltd, 1998)

Hall, Stuart, 'Gramsci's Relevance for the Study of Race and Ethnicity', in 
Stuart Hall: Critical Dialogues in Cultural Studies, ed. by David Morley and Kuan-Hsing Chen (London: Routledge, 1996), pp. 411-40 Harris, Clive, 'Post-War Migration and the Industrial Reserve Army', in Inside Babylon: The Caribbean Diaspora in Britain, ed. by Winston James and Clive Harris (London: Verso, 1993) pp. 9-54

Hesse, Barnor, 'Black to Front and Black Again', in Writing Black Britain: 1948-1998, ed. by James Procter (Manchester: Manchester University Press, 2000) pp. 78-82

Holman, Gordon, 'Double Guard on Men of Jamaica', and inset, 'Stowaway Avrll Got £50', Evening Standard, 22 June 1948

'Jamaicans Arrive to Seek Work', The Times, 23 June 1948, p. 2 James, Louis, 'The Disturbing Vision of George Lamming', in Other Britain, Other British, ed. by A. Robert Lee (London: Pluto Press, 1995), pp. 35-47

James, Winston, 'Migration, Racism and Identity Formation: The Caribbean Experience in Britain', in Inside Babylon: The Caribbean Diaspora in Britain, ed. by Winston James and Clive Harris (London: Verso, 1993), pp. 231-87

Malik, Sarita, Representing Black Britain: A History of Black and Asian Images on British Television (London: Sage, 2001)

Massey, Doreen, 'A Place Called Home?' New Formations 17 (1992), 3-15

McLeod, John, Postcolonial London: Rewriting the Metropolis (London: Routledge, 2004)

Mead, Matthew, 'Review of Imagining London by John Clement Ball, Postcolonial London by John Mcleod, and Black British Literature by Mark Stein', Journal of Postcolonial Writing 42 (2006), 119-21

Ministry of Labour. Question of placing Jamaican and other coloured colonial workers. Correspondence on Maltese immigration, the arrival of the HMT Ormonde with 100 Jamaicans on board in 1947, and the booking of more than 300 berths by Jamaican men on the Empire Windrush. LAB 81499. National Archives, London

Panayi, Panikos, 'Germans in London', in The Peopling of London: Fifteen

Thousand Years of Settlement from Overseas, ed. by Nick Merriman

(London: The Museum of London, 1993), pp. 111-17

Phillips, Caryl, A New World Order (New York: Vintage, 2001)

Procter, James, 'General Introduction: "1948”/"1998”-Periodising

Postwar Black Britain', in Writing Black Britain: 1948-1998: An 
Interdisciplinary Anthology, ed. by James Procter (Manchester: Manchester

University Press, 2000), pp. 1-12 (p. 1)

The Routledge Reader in Caribbean Literature, ed. by Alison Donnell and

Sarah Lawson Welsh (London: Routledge, 1996)

Safran, William, 'Diasporas in Modern Societies: Myths of Homeland and

Return', Diaspora, 1 (1991), 83-99

Sponza, Lucio, 'Italians in London' in The Peopling of London: Fifteen

Thousand Years of Settlement from Overseas, ed. by Nick Merriman

(London: The Museum of London, 1993), pp. 129-37

Stein, Mark, Black British Literature: Novels of Transformation (Columbus:

Ohio State University Press, 2004)

Sword, Keith, 'The Poles in London', in The Peopling of London: Fifteen

Thousand Years of Settlement from Overseas, ed. by Nick Merriman

(London: The Museum of London, 1993), pp. 154-62

Walvin, James, Passage to Britain: Immigration in British History and Politics

(Harmondsworth: Penguin, 1984)

Wambu, Onyekachi, 'Introduction', in Empire Windrush: Fifty Years of

Writing About Black Britain, ed. by Onyekachi Wambu (London:

Victor Gollancz, 1998), pp. 19-32 (p. 20)

Webster, Wendy, Imagining Home: Gender, 'Race' and National Identity,

1945-64 (London: UCL Press Ltd, 1998)

Williams, Claudette, 'We Are a Natural Part of Many Different Struggles:

Black Women Organising', in Inside Babylon: The Caribbean Diaspora in Britain, ed. by Winston James and Clive Harris (London: Verso, 1993), pp. 153-63

Winder, Robert, Bloody Foreigners: The Story of Immigration to Britain

(Chatham: Abacus, 2004)

Windrush: The Irresistible Rise of Multi-Racial Britain, ed. by Mike Phillips and Trevor Phillips (London: HarperCollins, 1998) 


\section{Endnotes}

1. Muhammad Anwar, "New Commonwealth" Migration to the UK', in The Cambridge Survey of World Migration, ed. by Robin Cohen (Cambridge: Cambridge University Press, 1995), pp. 274-78 (p. 274).

2. Paul Carter, The Road to Botany Bay: An Exploration of Landscape and History (New York: Alfred A. Knopf, 1988), p. xiv.

3. Caryl Phillips, 'The Pioneers: Fifty Years of Caribbean Migration to Britain', in A New World Order (New York: Vintage, 2001), pp. 264-282 (p. 264).

4. Peter Fryer, Staying Power: The History of Black People in Britain (London: Pluto Press Ltd, 1984), p. 374.

5. Phillips, p. 264.

6. According to Peter Fryer, 'In October 1948 the Orbita brought 180 to Liverpool, and three months later 39 Jamaicans, 15 of them women, arrived at Liverpool in the Reina del Pacifico' (Staying Power, p. 372). Clearly, those vessels docking at Liverpool or Southampton would not have a literal encounter with the white cliffs of Dover.

7. Gilroy, Paul, Small Acts: Thoughts on the Politics of Black Cultures (London: Serpent's Tail, 1993), p. 23.

8. Gilroy, p. 23-24.

9. Gilroy, p. 28.

10. Gilroy, p. 26.

11. Gilroy, p. 25.

12. Phillips, p. 265.

13. Windrush: The Irresistible Rise of Multi-Racial Britain, ed. by Mike Phillips and Trevor Phillips (London: HarperCollins, 1998), p. 6.

14. John McLeod, Postcolonial London: Rewriting the Metropolis (London: Routledge, 2004), p. 24.

15. Phillips, p. 268.

16. David Dabydeen, 'Introduction', Kunapipi, 20 (1998), n.p.

17. James Procter, 'General Introduction: "1948"/"1998”-Periodising Postwar Black Britain', in Writing Black Britain: 1948-1998: An Interdisciplinary Anthology, ed. by James Procter (Manchester: Manchester University Press, 2000), pp. 1-12 (p. 1).

18. Anwar, p. 274. 
19. The Routledge Reader in Caribbean Literature, ed. by Alison Donnell and Sarah Lawson Welsh (London: Routledge, 1996), p. 127.

20. Louis James, 'The Disturbing Vision of George Lamming', in Other Britain, Other British, ed. by A. Robert Lee (London: Pluto Press, 1995), pp. 35-47 (p. 35).

21. John Clement Ball, Imagining London: Postcolonial Fiction and the Transnational Metropolis (Toronto: University of Toronto Press, 2004), p. 4.

22. Clive Harris, 'Post-War Migration and the Industrial Reserve Army', in Inside Babylon: The Caribbean Diaspora in Britain, ed. by Winston James and Clive Harris (London: Verso, 1993) pp. 9-54 (p. 22).

23. Fryer, Staying Power, p. 372.

24. Vivienne Francis, With Hope in Their Eyes: The Compelling Stories of the Windrush Generation (London: Nia, 1998), n.p.

25. Barnor Hesse, 'Black to Front and Black Again', in Writing Black Britain: 1948-1998, ed. by James Procter (Manchester: Manchester University Press, 2000) pp. 78-82 (p. 79).

26. Wendy Webster, Imagining Home: Gender, 'Race' and National Identity, 1945-64 (London: UCL Press Ltd, 1998), p. 25.

27. Robert Winder, Bloody Foreigners: The Story of Immigration to Britain (Chatham: Abacus, 2004), p. 336.

28. Mark Stein, Black British Literature: Novels of Transformation (Columbus: Ohio State University Press, 2004), p. 229.

29. Peter Fraser, 'Africans and Caribbeans in London', in The Peopling of London: Fifteen Thousand Years of Settlement from Overseas, ed. by Nick Merriman (London: The Museum of London, 1993), pp. 51-61 (p. 57). 30. Winston James, 'Migration, Racism and Identity Formation: The Caribbean Experience in Britain', in Inside Babylon: The Caribbean Diaspora in Britain, ed. by Winston James and Clive Harris (London: Verso, 1993), pp. 231-87 (p. 286).

31. Sarita Malik, Representing Black Britain: A History of Black and Asian Images on British Television (London: Sage, 2001), p. 7.

32. Harry Goulbourne, Race Relations in Britain since 1945 (Basingstoke: Macmillan Press Ltd, 1998), p. 42.

33. Onyekachi Wambu, 'Introduction', in Empire Windrush: Fifty Years of Writing About Black Britain, ed. by Onyekachi Wambu (London: Victor Gollancz, 1998), pp. 19-32 (p. 20).

34. Fryer, Staying Power, p. 372. 
35. Webster, p. 25.

36. Wambu, p. 20.

37. Claudette Williams, 'We Are a Natural Part of Many Different Struggles: Black Women Organising', in Inside Babylon: The Caribbean Diaspora in Britain, ed. by Winston James and Clive Harris (London: Verso, 1993), pp. 153-63 (p. 154).

38. It is testament to the shorthand efficiency of the Windrush as a well understood cultural symbol, and to the compulsion to repeat, that many of the texts named here mobilise the Windrush myth as an opening gambit, either in a section of text or for an entire volume. Reviewing those volumes by McLeod, Stein, and Ball mentioned above in the Journal of Postcolonial Writing, I also opened with the arrival of the Empire Windrush, citing the date of arrival, the number of migrants, etc. As is often the case, the Windrush is twice a point of origin-once within the historical discourse of post-war migration, and again as the inauguration of the text of this history.

39. J. P. Gallagher, '500 Hope to Start a New Life Today', Daily Express, 21 June 1948, p. 1.

40. Peter Fryer, 'Five Hundred Pairs of Willing Hands', Daily Worker, 23 June 1948, p. 3.

41. 'Jamaicans Arrive to Seek Work', The Times, 23 June 1948, p. 2.

42. Doreen Massey, 'A Place Called Home?' New Formations 17 (1992), 3-15 (p. 11).

43. Massey, p. 11.

44. Webster, p. 25.

45. Board of Trade, London: MV Empire Windrush (New Zealand Shipping Company Ltd) Travelling from Kingston to London. Embarking at Kingston, Trinidad and Bermuda. Official Number: 181561. List of Passengers Disembarking at London. Passenger Log. BT 26123791. National Archives, London. This is confirmed by several Ministry of Labour and Colonial Office documents. To take a significant example, see F. B. Hawkins report to P. Holden at the Ministry of Labour entitled 'Disembarkation of Jamaicans from s. s. Windrush at Tilbury on 22nd June, 1948'. Ministry of Labour. Question of placing Jamaican and other coloured colonial workers. Correspondence on Maltese immigration, the arrival of the HMT Ormonde with 100 Jamaicans on board in 1947, and the booking of more than 300 berths by Jamaican men on the Empire 
Windrush. LAB 8 1499. National Archives, London. The former was an employee of the Ministry's regional office at Cambridge and was present at Tilbury on 21 and 22 June.

46. Gordon Holman, 'Double Guard on Men of Jamaica', and inset, 'Stowaway Avrll Got £50', Evening Standard, 22 June 1948. An interim report circulated by a Colonial Office employee, A. H. Poynton, on 30 June 1948, headed simply 'Empire Windrush', suggests that the number of stowaways was somewhere 'in the region of 20'. Colonial Office, Employment of Jamaicans from the SS Empire Windrush. CO 87688. National Archives, London.

47. Details of this exhibition can be found at <http://www.museumoflondon. org.uk/archive/exhibits/ windrush/windrush.htm>. Accessed 11 December 2006.

48. Stein, p. 202.

49. Stein, p. 4.

50. Gallagher, p. 1.

51. Keith Sword, 'The Poles in London', in The Peopling of London: Fifteen Thousand Years of Settlement from Overseas, ed. by Nick Merriman (London: The Museum of London, 1993), pp. 154-62 (p. 154).

52. Sword, p. 156.

53. Sword, pp. 154-62; James Walvin, Passage to Britain: Immigration in British History and Politics (Harmondsworth: Penguin, 1984)

54. William Safran, 'Diasporas in Modern Societies: Myths of Homeland and Return', Diaspora, 1 (1991), 83-99 (p. 85).

55. Walvin, p. 163.

56. Panikos Panayi, 'Germans in London', in The Peopling of London: Fifteen Thousand Years of Settlement from Overseas, ed. by Nick Merriman (London: The Museum of London, 1993), pp. 111-17; Lucio Sponza, 'Italians in London' in The Peopling of London: Fifteen Thousand Years of Settlement from Overseas, ed. by Nick Merriman (London: The Museum of London, 1993), pp. 129-37; Sword, pp. 154-62; Walvin, p. 163; Safran, pp. 83-99.

${ }^{57}$ Stuart Hall, 'Gramsci's Relevance for the Study of Race and Ethnicity', in Stuart Hall: Critical Dialogues in Cultural Studies, ed. by David Morley and Kuan-Hsing Chen (London: Routledge, 1996), pp. 411-40 (p. 415). ${ }^{58}$ Windrush: The Irresistible Rise of Multi-Racial Britain, ed. by Mike Phillips and Trevor Phillips (London: HarperCollins, 1998), p. 65. 